\title{
Protein Folding in the Endoplasmic Reticulum
}

\author{
Ineke Braakman ${ }^{1}$ and Daniel N. Hebert ${ }^{2}$ \\ ${ }^{1}$ Cellular Protein Chemistry, Faculty of Science, Utrecht University, Padualaan 8, 3584 CH Utrecht, \\ The Netherlands \\ ${ }^{2}$ Department of Biochemistry and Molecular Biology, University of Massachusetts, Amherst, \\ Massachusetts 01003 \\ Correspondence: i.braakman@uu.nl; dhebert@biochem.umass.edu
}

In this article, we will cover the folding of proteins in the lumen of the endoplasmic reticulum (ER), including the role of three types of covalent modifications: signal peptide removal, $\mathrm{N}$ linked glycosylation, and disulfide bond formation, as well as the function and importance of resident ER folding factors. These folding factors consist of classical chaperones and their cochaperones, the carbohydrate-binding chaperones, and the folding catalysts of the PDI and proline cis-trans isomerase families. We will conclude with the perspective of the folding protein: a comparison of characteristics and folding and exit rates for proteins that travel through the ER as clients of the ER machinery.

\begin{abstract}
$A_{d}^{n}$ newly synthesized protein entering the endoplasmic reticulum (ER) undergoes a series of modifications and encounters a number of molecular chaperones and folding enzymes that all together assist its proper folding and subsequent release from the ER. The majority of resident ER proteins are dedicated to the folding process. Molecular chaperones of the classical heat-shock protein (Hsp) families reside next to lectin chaperones that recognize a specific glycan composition on the folding protein. No chaperone works alone. Hsps couple client-binding cycles to ATPase cycles, which is regulated by functional classes of cochaperones, whereas the carbohydrate chaperones team up with a set of enzymes that support a functional chaperoning cycle. Folding enzymes catalyze disulfide bond formation or
\end{abstract}

proline cis-trans isomerization, both essential for physiological folding. Figure 1 illustrates that all well-known modifications in a protein may begin from the moment translation is initiated and the protein enters the ER, and that most modifications continue until the very last moment before the protein leaves the ER. $N$ linked glycosylation and signal peptide cleavage are thought to be complete earlier, and oligomerization happens with largely folded proteins in the ER and hence somewhat later than folding. At the end of the article, we will take the perspective of the client protein, and couple the characteristics of proteins to their folding and exit rates. This illustrates the enormous variety of ER clients that all are accommodated well by this versatile and robust folding compartment.

Editors: Susan Ferro-Novick, Tom A. Rapoport, and Randy Schekman

Additional Perspectives on The Endoplasmic Reticulum available at www.cshperspectives.org

Copyright (C) 2013 Cold Spring Harbor Laboratory Press; all rights reserved; doi: 10.1101/cshperspect.a013201

Cite this article as Cold Spring Harb Perspect Biol 2013;5:a013201 
I. Braakman and D.N. Hebert

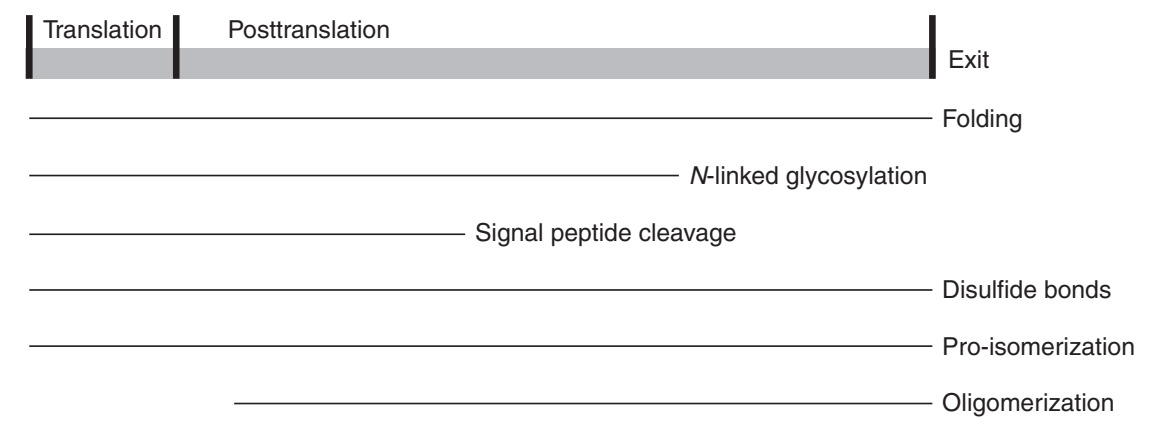

Figure 1. Parallel events during protein folding. The gray bar represents a time course, where folding starts during translation and continues until the protein has reached its native conformation and leaves the ER. If not properly folded or assembled it may exit as misfolded protein.

\section{PROTEIN PROCESSING AND MODIFICATION}

\section{Signal Sequence Cleavage}

Most proteins are cotranslationally targeted to the ER by signal sequences, which are commonly found in the first $\sim 25$ amino acids of a protein. Algorithms can identify putative signal peptides from a protein sequence (Petersen et al. 2011). Signal sequences are comprised of an aminoterminal basic domain (N-domain), a medial hydrophobic domain (H-domain), and a polar domain that contains the cleavage site (C-domain) (Hegde and Bernstein 2006). The Nand $\mathrm{H}$-domains help to position the peptide in a looped orientation during translocation with the amino-terminus facing the cytoplasm, the $\mathrm{H}$-domain in the core of the lipid bilayer and the C-domain facing the lumen for recognition and cleavage by the signal peptidase complex (SPC, Fig. 2). The nature of the signal sequence can affect the efficiency of targeting and the timing of cleavage, as well as have an impact on additional maturation steps.

The efficiency by which a protein is directed to and translocated into the ER varies dependent on the signal sequence. An example of inefficient targeting is with the Prion protein or PrP. PrP possesses a signal sequence that supports inefficient ER translocation, resulting in the accumulation of a fraction of PrP in the cytoplasm (Rane et al. 2010). Interestingly, replacement of the PrP signal sequence with a more efficient targeting sequence rescued mice from neurodegeneration caused by pathogenic PrP variants suggestive of the cytoplasmic protein displaying toxic effects. A second example is the inefficient translocation of the ER chaperone calreticulin, which appears to explain its dual localization in the cytoplasm/ nucleus and the ER lumen (Shaffer et al. 2005). These results show that the efficiency with which a signal sequence supports ER targeting and translocation can have functional consequences.

The timing of the cleavage of the signal sequence is protein dependent. Generally, it is considered to occur cotranslationally, however it has few test cases. For preprolactin, hemagglutinin, and tyrosinase, signal sequence cleavage occurs after their polypeptide chains reach lengths of $\sim 120$ amino acids (Nicchitta et al. 1995; Daniels et al. 2003; Wang et al. 2005). However, signal sequence cleavage for some proteins can also be a posttranslational event. For instance, the HIV envelope glycoprotein signal sequence is cleaved posttranslationally after the protein has folded to some degree ( $\mathrm{Li}$ et al. 1996; Land et al. 2003). Tethering the amino-terminus to the membrane during the initial stages of folding appears to help direct the early folding and maturation processes; and because of this the timing of cleavage can be important. Furthermore, for the ER protein EDEM1, inefficient signal sequence cleavage results in the production of proteins possessing dual topologies from a single transcript (Tamura et al. 2011). A soluble form of EDEM1 is produced when the signal sequence is cleaved and a type II membrane-anchored form accumulates when the amino-terminal 


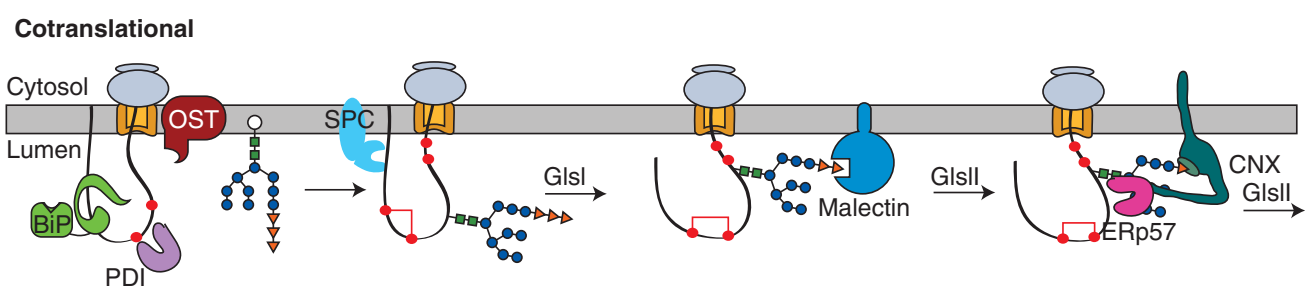

Posttranslational

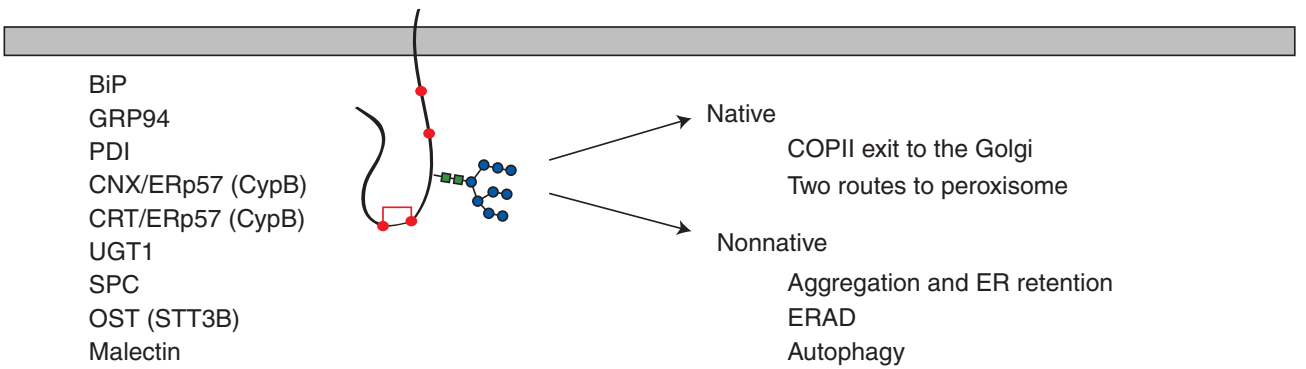

Figure 2. Co- and posttranslational protein folding in the ER lumen. Top panel, the ribosome (grey) sits on the Sec61 translocon (orange) to support cotranslational translocation of the nascent chain into the ER lumen. The oligosaccharyltransferase (OST) attaches preassembled glycans (tree structure) to Asn on the nascent chain. BiP (green) and PDI ( purple) are positioned for early assistance. Disulfide bonds start to form. The amino-terminal signal sequence is cleaved by the signal sequence peptidase complex (SPC, light blue). Glucosidase I (GlsI) removes the terminal glucose residue (orange triangle) from the $N$-linked glycan. The diglucosylated glycan can bind to the membrane-associated lectin, malectin (dark blue). Glucosidase II (GlsII) removes a second glucose to generate a monoglucosylated glycan structure that is bound to calnexin (CNX, green), a lectin chaperone associated with the oxidoreductase ERp57 (pink). Lectin chaperone binding continues until GlsII removes the final glucose residue. Bottom panel, the listed factors interact co- and posttranslationally, after the translation of the nascent chain has been completed. These factors help with maturation and the sorting of the native or nonnative protein for its various fates. Calreticulin (CRT) is a soluble paralogue of calnexin.

signal sequence remains intact. Recent evidence indicates that signal sequences do not simply provide transient targeting information, as the signal sequence can also influence folding, modification, localization, and the topology of a protein. The importance of the signal sequence is further underscored by the identification of a number of mutations in signal sequences associated with disease states (Ding et al. 2005; Piersma et al. 2006; Bonfanti et al. 2009).

\section{N-Linked Glycosylation}

Most proteins that traverse the eukaryotic secretory pathway are modified by $\mathrm{N}$-linked glycans on Asn residues found in the Asn-X-Ser/Thr sequence. The modifications are frequently added cotranslationally once the sequon reaches $\sim 13$ amino acids deep into the ER lumen, aligning the modification site of the Asn residue with the active site of the oligosaccharyltransferase (OST, Fig. 2) (Nilsson and von Heijne 1993). The hetero-oligomeric transferase complex en bloc transfers a preassembled carbohydrate comprised of three glucoses, nine mannoses, and two $\mathrm{N}$-acetyl glucosamines $\left(\mathrm{Glc}_{3} \mathrm{Man}_{9}\right.$ $\mathrm{GlcNAc}_{2}$ ) to the Asn residue. Alternatively, an OST complex containing a second isoform of the catalytic subunit (STT3B) is capable of posttranslationally modifying missed sequons, which are frequently found proximal to the carboxyl-terminus of a protein (Ruiz-Canada et al. 2009). Rapid folding and oxidation of a protein can diminish the level of glycosylation (ShakinEshleman et al. 1992; Allen et al. 1995). These protein modifications have intrinsic, as well as 
extrinsic effects on the stability and conformation of a protein. The extrinsic effects involve recruitment of carbohydrate-binding factors in the ER lumen that influence the maturation and sorting of the nascent chain and will be discussed in the molecular chaperones section below.

The addition of bulky hydrophilic carbohydrate modifications directly alters the inherent physical properties of a protein. $N$-linked glycans can improve both the kinetics and thermodynamics of folding for isolated proteins (Jitsuhara et al. 2002; Hanson et al. 2009). They can also increase the stability of the protein by masking hydrophobic stretches, proteolytic cleavage sites or immune recognition (Skehel et al. 1984; Kundra and Kornfeld 1999). Glycans most frequently appear on exposed loops on the surface of proteins (Zielinska et al. 2010). The large hydrophilic modification can direct the modified region to an aqueous exposed position. The introduction of glycosylation sites into a protein through mutation frequently stabilizes a protein by destabilizing the unfolded state thereby coaxing the protein toward the folded state (Hanson et al. 2009). The transferase reaction requires flexibility in the sequon, as the Thr/Ser residue in position 3 , is required to loop around to make the Asn nucleophilic for efficient transfer (Helenius and Aebi 2004; Lizak et al. 2011). This requirement favors the modification of flexible exposed regions of a protein. The necessity of a modification at a specific site is highly protein and site dependent. Whereas some sites of modification are absolutely required for efficient maturation, others are completely dispensable (Hebert et al. 1997; Wang et al. 2008). Sometimes the location is not critical but the total number of glycans is. Identification of obligatory modification sites and whether they are essential because of intrinsic or extrinsic needs requires empirical testing for their proper categorization and understanding.

\section{ER MOLECULAR CHAPERONES}

Maturing nascent chains are vulnerable to misfolding and aggregation as a result of the concentrated cellular environment reaching $300-$
$400 \mathrm{~g} \mathrm{~L}^{-1}$ protein (Ellis and Hartl 1999). Molecular chaperones are defined as proteins that aid other proteins in acquiring their native active conformation but are not part of the final protein structure (Ellis and Van der Vies 1991). Molecular chaperones are able to promote the efficient folding of proteins and prevent aggregation by providing a protected and privileged folding environment within the cell. To understand the mechanism by which chaperones assist in protein maturation and maintaining protein homeostasis (proteostasis), one must understand: how they recognize proteins, how their binding cycle is maintained, which cofactors are involved, and how these cofactors assist in substrate selection and the regulation of the chaperone-binding cycle.

The ER houses a number of molecular chaperones that are dedicated to the proper maturation and sorting of maturing nascent chains in the early secretory pathway. Two major chaperone systems are found in the ER: the classical chaperones and the carbohydrate-binding chaperone system. The classical chaperone system is found in almost all cellular locations and generally involves heat shock proteins that bind directly to the polypeptide chain. In contrast, the carbohydrate-binding chaperone system is specific for the ER and involves interactions with the hydrophilic glycan modification. These systems work together to ensure that protein flux through the ER is adequately maintained for the large variety of proteins that traverse the secretory pathway.

\section{Classical Chaperones}

The ER contains chaperones from both the Hsp70 and Hsp90 families of molecular chaperones. Chaperones identify immature, aberrant, or aggregation-prone proteins by the presence of exposed hydrophobic segments that are generally buried within the core of native proteins. They are recruited to assist in the maturation of nonglycosylated proteins or toward domains on glycosylated proteins that are unmodified. Furthermore, their binding is regulated by adenine-nucleotide binding and specialized cofactors. Despite these similarities, 
their range of substrates and roles in the ER are diverse.

The ER Hsp70 family member is called BiP in metazoans or Kar2p in yeast (Fig. 2). BiP is comprised of two domains: a highly conserved amino-terminal nucleotide-binding domain (NBD), and a carboxy-terminal substrate-binding domain (SBD). The SBD has a cleft that associates with the substrate. An extended lid that can open and close onto the cleft controls substrate binding. When ATP is bound to the $\mathrm{NBD}$, the lid is open leaving the SBD in the low affinity conformation. Upon ATP hydrolysis, ADP is bound to the NBD and the lid closes on the bound substrate. This creates a low off rate for high-affinity substrate binding and protects the bound substrate from premature folding or aggregation. Exchange of ADP for ATP results in the opening of the lid and subsequent release of the substrate, which then is free to fold. A number of BiP cofactors have been discovered that assist with controlling the substrate-binding cycle and its localization within the ER.

Nucleotide exchange factors (NEF) assist in the transition from the ADP to the ATP bound state for $\mathrm{BiP}$, thereby catalyzing the release of substrate. BAP/Sill and GRP170 are the mammalian NEF for BiP (Chung et al. 2002). BAP/ Sill assists in the release of substrates from $\mathrm{BiP}$ by promoting the release of $\mathrm{ADP}$ from $\mathrm{BiP}$. $\mathrm{Mu}$ tations in BAP/Sill are associated with $\mathrm{Ma}$ rinesco-Sjögren syndrome, a form of ataxia and cerebellar atrophy (Anttonen et al. 2005; Senderek et al. 2005). A mouse knockout of BAP/Sill provides a model for MarinescoSjögren syndrome (Zhao et al. 2005).

Hsp70 hydrolysis of ATP to ADP is accelerated by Hsp40 family members or so-called Jdomain proteins. The J-domain binds to Hsp70 and stimulates its ATPase activity. In addition to controlling the localization and activity of Hsp70s, J-domain proteins may also bind the substrate themselves and help with the initial delivery of the substrate to the Hsp70 chaperone. In the mammalian ER, there are seven J-domain proteins (ERdj1-7) that assist with the diverse functions of $\mathrm{BiP}$ in the $\mathrm{ER}$ (Otero et al. 2010). ERdj1/Mtj1p and ERdj2/Sec63 are membrane-embedded and translocon-associat- ed J-proteins. They assist with the positioning of an activated $\mathrm{BiP}$ at the translocon pore to help with the early maturation of nascent chains and control the permeability barrier potentially compromised by the presence of a translocon pore in the ER membrane (Molinari and Helenius 2000; Alder et al. 2005; Schauble et al. 2012). ERdj3/HEDJ and ERdj6/p58IPK bind to nascent or unfolded proteins suggestive of their playing a role in the protein folding process. In contrast, ERdj4/Mdg1 and ERdj5/JPDI associate with misfolded proteins and help to accelerate their turnover. The role for the most recently discovered ER J-domain protein, ERdj7, is unknown.

$\mathrm{BiP}$ has been referred to as the master regulator of the ER because of the broad roles it plays in ER processes and functions (Hendershot 2004). BiP promiscuously binds to the majority of proteins that traverse the ER at some point during their stay in the ER. It has been estimated that a BiP-binding site is observed on average every 40 amino acids within a protein (Flynn et al. 1991; Blond-Elguindi et al. 1993).

There are few confirmed bona fide substrates of GRP94 although it is one of the most abundant proteins of the ER. GRP94 is an essential gene in metazoans as it is required for early developmental stages in mice, Arabidopsis, Drosophila, and C. elegans (Ishiguro et al. 2002; Wanderling et al. 2007; Baviskar and Shields 2010; Maynard et al. 2010), yet many unanswered questions remain about its role in ER homeostasis and its mechanism of action. Surprisingly the activity of GRP94 in unicellular organisms is not essential or in some cases such as yeast, it is even absent. GRP94 is organized into an amino-terminal domain (NTD), a middle domain (MD), and a carboxy-terminal domain (CTD). As with BiP, the NTD is the adenine nucleotide-binding domain and the nucleotide-binding influences the opening and closing of the chaperone. Geldanamycin, radicicol, and their derivatives bind to the NTD and inhibit the activity of the chaperone by converting the chaperone to its closed conformation (Wearsch et al. 1998; Schulte et al. 1999; Vogen et al. 2002; Soldano et al. 2003). The NTD also contains a charged linker domain that supports 
calcium and cochaperone binding, and controls ATP hydrolysis (Schulte et al. 1999; Vogen et al. 2002; Hainzl et al. 2009). The MD possesses a large loop that interacts with and controls the ATP-binding site along with a hydrophobic patch important for domain interactions (Dutta and Inouye 2000). The CTD supports homo-dimerization of GRP94, which is allosterically regulated by adenine nucleotide binding to support the opening and closing of the dimer (Yamada et al. 2003). The carboxy-terminal peptide of KDEL acts as an ER retention and retrieval sequence.

The substrate-binding site for GRP94 has not yet been elucidated. This may be attributable to there being a large surface of interactions. All states of the chaperone can exist at all nucleotide states, and each nucleotide state stabilizes a particular conformation. The addition of ATP appears to stabilize the chaperone in the closed state, with the open state being stabilized on ATP hydrolysis but the effect of this on substrate binding unlike with $\mathrm{BiP}$ is not as clear. For cytoplasmic Hsp90, this shift is also assisted by cochaperones but currently GRP94 has no cochaperones in the ER known to regulate its conformation. CNPY3 (PRAT4A) and OS-9 have been shown to associate with GRP94 as possible cofactors; however, the precise roles for these proteins are uncertain. In the case of OS-9, which is a lectin quality-control receptor that targets aberrant glycoproteins for turnover by the ER-associated degradation pathway, GRP94 knockdown stabilizes the classic ERAD substrate $\alpha-1$-antitrypsin null Hong Kong (Christianson et al. 2008). This result suggests that OS-9 might be a cofactor of GRP94 that helps in the selection and targeting of ERAD substrates.

GRP94 client proteins appear to be more restricted than those observed for other abundant chaperones. Some of the maturing substrates that GRP94 associates with include immunoglobulin family members, integrins, thyroglobulin, and insulin-like growth factors (Randow and Seed 2001; Berwin et al. 2003; Srivastava 2006; Ostrovsky et al. 2009). Although mouse knockouts are embryonic lethal, tissue-specific knockouts to the musculature allow the mice to survive, but they are much smaller (Wanderling et al. 2007). This has been attributed to the lack of production of IGFs, obligate substrates of GRP94. Currently, it is not clear what properties GRP94 recognizes in a substrate. Ig initially interacts with $\mathrm{BiP}$ before being passed over to GRP94, suggesting that GRP94 acts later during the maturation process (Melnick et al. 1994), similar to what has been observed for Hsp90s. Whereas recent progress has been gained over the years in understanding the function of GRP94 in the ER, there are still many unanswered questions about the mechanism of action for this enigmatic ER chaperone.

\section{Carbohydrate-Binding Chaperones}

Beyond the intrinsic influence of glycans on protein maturation and stability, $N$-linked glycans also play an important role in the recruitment of maturation and quality-control factors in the ER (Hebert et al. 2005; Pearse and Hebert 2010). After the transfer of the 14-member glycan, the glycan is rapidly cotranslationally trimmed of a terminal glucose residue by glucosidase I, to create diglucosylated modifications. This glucosetrimmed modification has reduced affinity for the OST (Fig. 2) (Hubbard and Robbins 1979; Lehrman 2001). Furthermore, malectin, an ER lectin, was recently characterized and shown to bind specifically to proteins possessing diglucosylated glycans (Schallus et al. 2008). As this glycan composition is generally present at early stages during the cotranslational program, this suggests that malectin is involved in early maturation steps. Malectin was found to associate with endogenous aquaporin-2 in a large-scale proteomics study (Barile et al. 2005). However, recent studies suggest that malectin binds aberrant substrates in the ER (Chen et al. 2011; Galli et al. 2011). This raises the question if malectin acts early in the maturation process, how can it already distinguish between native and aberrant proteins? Future studies involving malectin will be required to sort out its function in the ER.

The subsequent and sequential trimming by glucosidase II of the diglucosylated protein to the eventual unglucosylated protein does not occur in a simple processive manner. 
The monoglucosylated state has been shown to persist for varying periods of time as it associates with the carbohydrate-binding chaperones calnexin and calreticulin (Suh et al. 1989; Hammond et al. 1994; Hebert et al. 1995; Peterson et al. 1995). Calnexin, a type I membrane protein, and calreticulin, its soluble paralogue, both possess a singular globular carbohydrate-binding domain (Schrag et al. 2001). Calnexin and calreticulin promote the efficient folding of glycoproteins by: (1) stabilizing folding events or slowing the folding process in a domain specific manner (Hebert et al. 1996, 1997; Daniels et al. 2003); (2) preventing aggregation and turnover (Hebert et al. 1996; Vassilakos et al. 1996); (3) retaining nonnative substrates in the ER to support additional attempts for proper folding ( Rajagopalan et al. 1994); (4) facilitating the formation of disulfide bond formation through their association with the oxidoreductase ERp57 (Oliver et al. 1997; Zapun et al. 1998; Solda et al. 2006); and (5) perhaps facilitating Pro isomerization through association with the PPIase CypB (Kozlov et al. 2010). More information on how oxidoreductases catalyze the formation of disulfide bonds can be found below (PDIs or oxidoreductases) and in Bulleid (2012).

The lectin chaperone or calnexin-binding cycle is regulated by the glucosidases and a glucosyltransferase that control the glucose composition of the glycan. Binding is initiated after glucosidase II removes a glucose residue to generate the monoglucosylated protein. Binding is also inhibited or ceases after glucosidase II action, which removes the final glucose to generate the unglucosylated protein. The released substrate is now free to fold. If after a single round of lectin chaperone binding a nonnative conformation persists, the quality-control sensor UGT1 (UDP-glucose: glycoprotein glucosyltransferase 1) will transfer a glucose back onto the unglucosylated glycoprotein, regenerating monoglucosylated glycans (Labriola et al. 1995; Sousa and Parodi 1995; Pearse et al. 2008). The reglucosylated substrate can then reassociate with the lectin chaperones to continue with attempts to fold properly (Hammond et al. 1994; Hebert et al. 1995; Van Leeuwen and Kearse 1997; Wada et al. 1997; Molinari et al. 2005; Pearse et al. 2008; Pearse and Hebert 2010).

UGT1 contains an amino-terminal folding sensor domain and a carboxy-terminal transferase domain (Arnold and Kaufman 2003; Guerin and Parodi 2003). UGT1 modifies glycans based on the structural integrity of the glycoprotein substrate (Caramelo and Parodi 2008). Studies using purified UGT1 and engineered substrates have showed that UGT1 recognizes near-native molten globule substrates through surface-exposed hydrophobic patches (Sousa and Parodi 1995; Caramelo et al. 2003, 2004). More recent studies using a cell-based reglucosylation assay revealed that the magnitude of substrate misfolding determines the level of reglucosylation and that reglucosylation occurs posttranslationally (Pearse et al. 2008). Therefore, proteins that are able to fold properly without the help of the lectin chaperones or after a single round of binding are not subjected to reglucosylation and further lectin chaperone binding. However, a large number of substrates are reglucosylated by UGT1 and in the case of the obligate UGT1 substrate prosaposin, reglucosylation is required for its efficient exit from the ER (Pearse et al. 2010). The reliance on the lectin chaperone-binding system for proper maturation is highly protein dependent.

\section{ER FOLDING ENZYMES}

Enzymes are catalysts, which do not influence the final equilibrium of a reaction, but increase the rate with which equilibrium is reached. This means that folding enzymes catalyze rate-limiting reactions during folding, but do not change the equilibrium directly. They may well do so indirectly, because they change the energy landscape of the folding process and hence may influence which of the many folding pathways available to a protein are favored over others. The two classes of folding enzyme activities, oxidation-reduction (4.A) and proline isomerization (4.B), illustrate the true nature of catalysts, as each can catalyze both directions of the reaction. The direction of the reaction is determined by environmental conditions such as redox state, by the folding protein, and by the driving forces 
of folding, which include burial of hydrophobic residues in a soluble protein, formation of hydrogen bonds, and electrostatic interactions. Many oxidoreductases do favor one direction over the other, because of their own redox potential (see Bulleid 2012).

\section{PDIs or Oxidoreductases}

Protein disulfide isomerase (PDI) is the first discovered, most abundant and best-characterized oxidoreductase in the ER (Wallis and Freedman 2011), which resulted in its class of oxidoreductases being nicknamed "the PDIs." Depending on conditions, it catalyzes formation, isomerization, or reduction of disulfide bonds. It is considered to have broad substrate specificity, or in other words, perhaps hardly any substrate specificity. More than 20 mammalian oxidoreductases have been identified with varying redox potential, substrate specificity, and perhaps also tissue specificity (Ellgaard and Ruddock 2005; Braakman and Bulleid 2011). Bulleid (2012) covers disulfide bond formation and the involved oxidoreductases in more detail.

Up to now, PDI appears unique for a folding enzyme in that it also has chaperone activity. Its $\mathrm{b}^{\prime}$ domain, which has a thioredoxin fold without an active site, binds hydrophobic peptides (Klappa et al. 1995). This combination of a chaperone and a folding enzyme is not unique, but PDI is the only folding assistant thus far known that pairs both activities within a single molecule.

The $\mathrm{b}^{\prime}$ domain in family member ERp57 has peptide affinity as well, but is used to bind calnexin and calreticulin, forming a bimolecular pair of chaperone and folding enzyme (Oliver et al. 1999; Frickel et al. 2002; Pollock et al. 2004). It may compete with PPIases for this position, as СypB was found to share this binding site on calnexin and calreticulin (Kozlov et al. 2010). For other oxidoreductases, chaperone activity has not been found (yet) but it is clear that the ER-resident folding assistants work in large (mostly transient) complexes rather than alone (Meunier et al. 2002; Kleizen and Braakman 2004; Jansen et al. 2012).
Without oxidoreductase capacity in the ER, protein folding would be too slow and prone to disaster, with abundant aggregation and degradation favored. Considering that protein folding in principle is a spontaneous process and that chaperones guide the process, the formation of nonnative disulfide bonds during folding is a must. Reduction of nonnative, erroneous disulfide bonds therefore are at least as important as native disulfide formation. How do reductases distinguish between native disulfide bonds that need to be left untouched and nonnative disulfide bonds that need to be broken? Perhaps they do not distinguish. Reductases likely reduce any disulfide bonds they encounter without regard for context or function. The secret may lie in the burial of native disulfides inside the folding and folded protein, as a result of hydrophobicity of the cysteine and cooperativity of folding in the region surrounding the disulfide bond. Native disulfide bonds simply are not accessible anymore, as illustrated by the high resistance to reducing agents of folded proteins (Tatu et al. 1993). Whereas disulfide-bond formation follows folding and does not drive protein folding directly, disulfide-stabilized folding intermediates do drive the equilibrium of the sequential folding steps forward, away from the unfolded state and toward the folded state of the newly synthesized protein.

PPIs

Often ignored but crucial for protein folding is the activity of the prolyl peptidyl cis-trans isomerases (PPIases). The vast majority of proteins have proline residues, and these residues are inserted by the ribosome in the trans conformation. As a consequence, all cis-proline residues in the native, folded protein structure have isomerized from trans to cis and can be assisted by PPIase activity. Native trans-proline residues may also have undergone isomerization from trans to cis and back to trans, perhaps multiple times during the folding process.

In vitro the PPIase enzymatic activities have been well-characterized (Lang et al. 1987). From those studies, it has become clear that proline isomerization is much too slow a process and 
hence rate-limiting for folding. On the other hand, deleting proline residues, which forces proteins in a more cis-conformation, strongly affects folding pathways and rates as well (Brandts et al. 1977; Pappenberger et al. 2001). These studies have been performed with small proteins, but the average protein in the secretory pathway is much larger, consists of multiple domains, and a number of proline residues. Folding of large proteins is likely initiated in more than one nucleus, allowing simultaneous folding of certain domains, but this does not make proline isomerization less rate limiting.

Cis-trans isomerization of peptide bonds of nonproline residues has been completely ignored in biology but considered to be slow as well (Brandts et al. 1977). The bacterial Hsp70 DnaK was shown to catalyze this so-called APIase reaction (for amide peptide bond cistrans isomerase), but it is unknown whether this is a general activity of Hsp70 proteins (Schiene-Fischer et al. 2002).

Most cellular compartments have members of two of the three PPIase families, the cyclophilins and the FK-binding proteins (FKBPs). Only the cyclophilins are inhibited by cyclosporine A, whereas only the FKBPs are inhibited by FK506, both immunosuppressive drugs are used for life-long treatment of organ-transplant recipients. This clinical activity of the drugs has been ascribed to an effect on the cytosolic family members, but the ER-resident proteins are inhibited effectively as well, illustrative of the similar mechanisms of activity within each family. The ER contains cyclophilins B and C, and FKBPs 2, 7, 9, 10 (also numbered 13, 23, 60, and 65 , respectively), 11, 14, and perhaps more, as most of these proteins have been poorly characterized.

As for the oxidoreductases, little is known for the PPIases concerning their redundancy and specificity. The few proteins that have been subjected to PPIase inhibition during their folding were affected by both CsA and FK506, suggesting action from both PPIase families on the same protein. These studies do not allow distinction between both enzyme families acting on the same substrate molecule versus one acting on one folding protein and the other on another, but the cyclophilins and FKBPs have not been found in the same resident ER protein complexes (Meunier et al. 2002; Kleizen and Braakman 2004; Jansen et al. 2012), so perhaps they work through different interactions in different chaperone complexes on different substrates or at different times during substrate folding. Studies on family members have shown that purified FKBPs lose their high sequence specificity and turn into effective broad PPIases when attached to or collaborating with a chaperone (Knappe et al. 2007; Jakob and Schmid 2009).

\section{Proximity of Cysteines and Prolines}

Secretory proteins have disulfide bonds, and the majority of proline residues are very close to disulfide bonds in the primary sequence. This suggests an abundant role for proline isomerization during disulfide bond formation and isomerization and vice versa. Inspiring then are the findings that individual PPIases and PDIs were found to interact (Jansen et al. 2012) and that cyclophilin B (СypB) associates with the tip of the finger domain of calnexin and calreticulin, sharing its binding site with ERp57's b' domain (Kozlov et al. 2010). Whether these are stable interactions or whether the lectin chaperones bring an alternating enzyme to the folding protein remains to be seen.

\section{CARGO PERSPECTIVE}

Newly synthesized proteins that enter the ER obtain different topologies, as soluble, single pass or multipass membrane proteins. A selection of studied cargo proteins is listed in Table 1, which illustrates the broad variety of secretory pathway cargo. Yet, all these proteins need to fold and assemble into their functional conformation, acquiring the necessary modifications in the process. Transmembrane domains need to assemble and cytosolic domains need to fold. Putative intramembrane chaperones have been reported, e.g., calnexin (Swanton and Bulleid 2003) and Bap31 (Lambert et al. 2001), and cytosolic domains are assisted by cytosolic chaperones. 


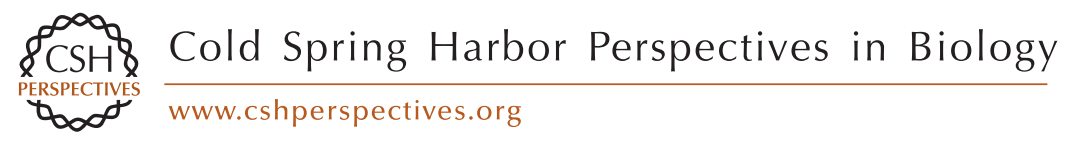

\begin{tabular}{|c|c|c|c|c|c|c|c|c|}
\hline Type & Protein & AA (with SP) & Cys & $\mathrm{N}-\mathrm{CHO}$ & Pro & $\begin{array}{c}\text { Secretion } \\
\text { time (approx.) }\end{array}$ & Level & References \\
\hline \multirow[t]{17}{*}{ Soluble } & Insulin & $86(110)$ & 6 & 0 & 6 & $35 \mathrm{~min}$ & ND & (Straub and Sharp 2002) \\
\hline & RNase (bovine) & $124(150)$ & 8 & 1 & 4 & $35 \mathrm{~min}$ & $59 \%$ & (Geiger et al. 2011) \\
\hline & RNase (human) & $127(156)$ & 8 & 3 & 7 & $27 \mathrm{~min}$ & $73 \%$ & (Geiger et al. 2011) \\
\hline & MD2 & $142(160)$ & 7 & 2 & 7 & $2 \mathrm{~h}$ & $90 \%$ & (Visintin et al. 2001) \\
\hline & Cp SFV & $148(172)$ & 0 & 0 & 7 & $40 \mathrm{~min}$ & $72 \%$ & (Thor et al. 2009) \\
\hline & $\alpha_{2}$-HS-glycoprotein & $348(367)$ & 14 & 2 & 39 & $25 \mathrm{~min}$ & $70 \%$ & (Rutkevich et al. 2010) \\
\hline & $\mathrm{AlAT}$ & $394(410)$ & 1 & 3 & 17 & $44 \mathrm{~min}$ & $40 \%$ & $\begin{array}{r}\text { (Lodish and Kong 1984; } \\
\text { Rutkevich et al. 2010) }\end{array}$ \\
\hline & $\operatorname{IgG}_{2 \mathrm{~b}}$ & $457(476)$ & 13 & 2 & 37 & $100 \mathrm{~min}$ & $60 \%$ & (Hendershot et al. 1987) \\
\hline & gp120 LAI & $486(516)$ & 18 & 23 & 22 & $2 \mathrm{~h}$ & $40 \%$ & (Land et al. 2003) \\
\hline & HA anchor- A/Japan/305/1957 (H2N2) & $509(524)$ & 12 & 4 & 18 & $1 \mathrm{~h}$ & $>90 \%$ & (Singh et al. 1990) \\
\hline & Alkaline-phosphatase & $513(535)$ & 5 & 2 & 31 & $30 \mathrm{~h}$ & ND & (Aldag et al. 2011) \\
\hline & HA anchor- A/Aichi/2/1968 (H3N2) & $513(531)$ & 12 & 7 & 20 & $1 \mathrm{~h}$ & $>90 \%$ & (Singh et al. 1990) \\
\hline & Albumin & $584(609)$ & 35 & 0 & 24 & $45 \mathrm{~min}$ & $>80 \%$ & (Rutkevich et al. 2010) \\
\hline & $\alpha$-Fetoprotein & $590(609)$ & 32 & 1 & 21 & $45 \mathrm{~min}$ & $100 \%$ & (Rutkevich et al. 2010) \\
\hline & Transferrin & $679(698)$ & 40 & 2 & 32 & $1 \mathrm{~h}$ & $80 \%$ & (Rutkevich et al. 2010) \\
\hline & Factor $\mathrm{V}$ & $2196(2224)$ & 19 & 26 & 151 & $3 \mathrm{~h}$ & $\sim 100 \%$ & (Duga et al. 2003) \\
\hline & Thyroglobulin & $2749(2768)$ & 122 & 17 & 173 & $1 \mathrm{~h}$ & $50 \%$ & (Kim and Arvan 1991) \\
\hline \multirow[t]{10}{*}{ Single pass } & NA A/WSN/33 (H1N1) & 453 & 19 & 4 & 21 & $30-60 \mathrm{~min}$ & ND & $\begin{array}{l}\text { (Hogue and Nayak 1992; } \\
\text { Popp et al. 2012) }\end{array}$ \\
\hline & VSVG & $495(511)$ & 12 & 2 & 27 & $30-60^{\mathrm{a}} \min$ & $80 \%-100 \%{ }^{\mathrm{a}}$ & (Doms et al. 1988) \\
\hline & Tyrosinase & $511(529)$ & 15 & 6 & 33 & $30 \mathrm{~min}$ & $38 \%^{\mathrm{b}}$ & (Popescu et al. 2005) \\
\hline & HA & $550(566)$ & 12 & 7 & 20 & $20 \mathrm{~min}$ & $100 \%$ & (Braakman et al. 1991) \\
\hline & Transferrin $\mathrm{R}$ & $734(760)$ & 6 & 3 & 31 & $3 \mathrm{~h}$ & $50 \%$ & (Lodish et al. 1983) \\
\hline & TLR2 & $748(766)$ & 13 & 4 & 25 & $3 \mathrm{~h}$ & $50 \%$ & (Lin et al. 2000) \\
\hline & gp160 Env BH8 & $821(851)$ & 20 & 28 & 29 & $2 \mathrm{~h}$ & $\sim 35 \%$ & (Earl et al. 1991) \\
\hline & gp160 Env LAI & $831(861)$ & 20 & 29 & 29 & $4 \mathrm{~h} / 20 \mathrm{~h}^{\mathrm{a}}$ & $30 \% / 30 \%$ & $\begin{array}{l}\text { (Bird et al. 1990; } \\
\text { Land et al. 2003) }\end{array}$ \\
\hline & LDL R & $836(860)$ & 61 & 3 & 39 & $1 \mathrm{~h}$ & $50 \%{ }^{\mathrm{c}}$ & (Jansens et al. 2002) \\
\hline & EGF R & $1210(1186)$ & 50 & 12 & 75 & $1.5 \mathrm{~h}$ & $50 \%$ & (Gamou et al. 1989) \\
\hline
\end{tabular}




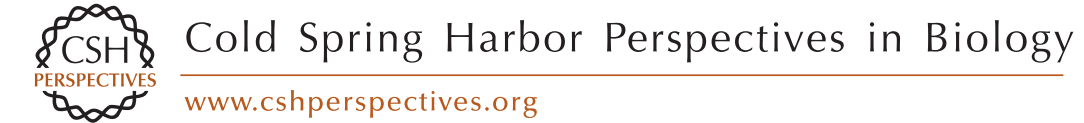

Table 1. Continued

\begin{tabular}{|c|c|c|c|c|c|c|c|c|}
\hline Type & Protein & AA (with SP) & Cys & $\mathrm{N}-\mathrm{CHO}$ & Pro & $\begin{array}{c}\text { Secretion } \\
\text { time (approx.) }\end{array}$ & Level & References \\
\hline \multirow[t]{6}{*}{ Multi-pass } & Aquaporin2 & 271 & $1(4)$ & 1 & 14 & $\sim 1.5 \mathrm{~h}$ & $\sim 50 \%$ & (Hendriks et al. 2004) \\
\hline & hACH R & 482 & 8 & 1 & 31 & $1.5 \mathrm{~h}$ & $30 \%$ & (Merlie and Lindstrom 1983) \\
\hline & Shaker $\mathrm{K}^{+}$channel & 656 & 2 & 2 & 32 & $45 \mathrm{~min}$ & ND & $\begin{array}{l}\text { (Schulteis et al. 1995; } \\
\text { Khanna et al. 2001) }\end{array}$ \\
\hline & hCFTR in BHK cells & 1454 & $0(18)$ & 2 & 45 & $\sim 2 \mathrm{~h}$ & $50 \%$ & (Mendes et al. 2003) \\
\hline & hCFTR in HeLa cells & 1454 & $0(18)$ & 2 & 45 & $\sim 1 \mathrm{~h}$ & $80 \%$ & (Hoelen et al. 2010) \\
\hline & hCFTR in HEK293 cells & 1454 & $0(18)$ & 2 & 45 & $\sim 1 \mathrm{~h}$ & $50 \%$ & (Zhang et al. 2002) \\
\hline
\end{tabular}

The number of amino acids in a protein is designated without and with (parentheses) signal sequences included. $N$-CHO indicates the predicted number of $\mathrm{N}$-linked glycans. The number of Cys in the luminal ectodomain of transmembrane proteins is indicated in parentheses. Secretion times and levels are approximate values.

${ }^{\mathrm{a}}$ Depending on expression system and cells.

${ }^{\mathrm{b}}$ Reaches melanosomes rather than the plasma membrane.

${ }^{c} \mathrm{~T}_{1 / 2}$ of glycan maturation endo $\mathrm{H}$ resistance. 
The folding assistants in each of these compartments will also be responsible for the triage and sorting of the folding protein population, constantly determining their fate and destination (Fig. 2, bottom panel). When properly folded, they may stay in the ER and function there or leave the compartment via one of at least two routes to the peroxisome (van der Zand et al. 2012), or to the Golgi and beyond ( plasma membrane, endosome, lysosome, or be secreted). When not properly folded and essentially "given up" by the ER, the protein may stay in the ER as aggregate, perhaps until the cell is cleared by apoptosis, or leave for degradation by the proteasome or by autophagy.

How does an ER client choose its assistants? And what determines how much time a protein requires for its folding and assembly processes? The first 50 amino acids were shown to be crucial for the choice between lectin or classical chaperones but that is only the first of many choices (Molinari and Helenius 2000). Table 1 shows that the extent to which a protein needs covalent modifications does not correlate with its folding rate or efficiency. The number of proline residues, disulfide bonds, or $\mathrm{N}$-glycans also do not seem to make a difference. Size appears to matter less than intuition would predict, probably because larger proteins consist of multiple domains, which each may need their own set of helpers, but which often may fold in parallel. This might explain why so many proteins take around $1-2 \mathrm{~h}$ to be secreted. The variation in protein identity is enormous, and there is not a single type of protein that is not accommodated by the compartment.

The rate-limiting step for the secretion of secretory proteins or the appearance at the plasma membrane for membrane protein is generally thought to be the rate of exit from the ER. Biosynthesis in or at the ER, including folding, modifications, and assembly, hence is the most crucial step for efficient secretion. Efficient is defined not only as fast, but also as high yield, which is another large difference between cargo proteins traveling the ER. The levels that reach their destination (Table 1) are disappointingly low, either because of degradation or because a fraction of all proteins exit with such delay that the radioactive pulse-chase analyses fail to analyze at such long chase times because cell proliferation is faster.

Once proteins leave the ER in native and hopefully functional form, they can do so because the chaperones and folding enzymes release them. For as long as proteins are in the ER, they can still unfold and aggregate, loose disulfide bonds or bound calcium ions, allowing yet another chance to reach the native conformation (Braakman et al. 1992a,b; Pena et al. 2010). Chaperone unfolding of terminal misfolded proteins can also render them translocation competent for eventual dislocation to the cytoplasm for proteasomal degradation through the ERAD pathway. When a protein has left the ER and entered the Golgi, they are as a general rule active functional structures having passed the ER quality-control test and resistant to reduction, oxidation, calcium depletion, and ATP reduction, oxidation, and calcium and ATP depletion (Braakman et al. 1992b; Tatu et al. 1993; Pena et al. 2010).

\section{ACKNOWLEDGMENTS}

This work is supported by U.S. Public Health grants GM086874 and GM094848 to D.N.H. and grants from the Netherlands Organization for Scientific Research, Chemistry Council (NWO-CW) to I.B. Members of the I.B. and D.N.H groups are acknowledged for critical reading of the manuscript (Kshama Chandrasekhar and Adabella van der Zand) and for help in assembling Table 1 (Kshama Chandrasekhar, Sabine Gremme, Abhinav Pandey, and Li Xin).

\section{REFERENCES}

* Reference is also in this collection.

Aldag I, Bockau U, Rossdorf J, Laarmann S, Raaben W, Herrmann L, Weide T, Hartmann MW. 2011. Expression, secretion and surface display of a human alkaline phosphatase by the ciliate Tetrahymena thermophila. BMC Biotechnol 11: 11.

Alder NN, Shen Y, Brodsky JL, Hendershot LM, Johnson AE. 2005. The molecular mechanisms underlying BiPmediated gating of the Sec61 translocon of the endoplasmic reticulum. J Cell Biol 168: 389-399. 
Allen S, Naim HY, Bulleid NJ. 1995. Intracellular folding of tissue-type plasminogen activator. Effects of disulfide bond formation on $N$-linked glycosylation and secretion. J Biol Chem 270: 4797-4804.

Anttonen AK, Mahjneh I, Hamalainen RH, Lagier-Tourenne C, Kopra O, Waris L, Anttonen M, Joensuu T, Kalimo H, Paetau A, et al. 2005. The gene disrupted in Marinesco-Sjogren syndrome encodes SIL1, an HSPA5 cochaperone. Nat Genet 37: 1309-1311.

Arnold SM, Kaufman RJ. 2003. The noncatalytic portion of human UDP-glucose: Glycoprotein glucosyltransferase I confers UDP-glucose binding and transferase function to the catalytic domain. J Biol Chem 278: 43320-43328.

Barile M, Pisitkun T, Yu MJ, Chou CL, Verbalis MJ, Shen RF, Knepper MA. 2005. Large scale protein identification in intracellular aquaporin-2 vesicles from renal inner medullary collecting duct. Mol Cell Proteomics 4: 1095-1106.

Baviskar SN, Shields MS. 2010. RNAi silenced Dd-grp94 (Dictyostelium discoideum glucose-regulated protein $94 \mathrm{kDa}$ ) cell lines in Dictyostelium exhibit marked reduction in growth rate and delay in development. Gene Expr 15: $75-87$.

Berwin B, Hart JP, Rice S, Gass C, Pizzo SV, Post SR, Nicchitta CV. 2003. Scavenger receptor-A mediates gp96/GRP94 and calreticulin internalization by antigen-presenting cells. EMBO J 22: 6127-6136.

Bird C, Burke J, Gleeson PA, McCluskey J. 1990. Expression of human immunodeficiency virus 1 (HIV-1) envelope gene products transcribed from a heterologous promoter. Kinetics of HIV-1 envelope processing in transfected cells. J Biol Chem 265: 19151-19157.

Blond-Elguindi S, Cwirla SE, Dower WJ, Lipshutz RJ, Sprang SR, Sambrook JF, Gething M-JH. 1993. Affinity panning of a library of peptides displayed on bacteriophages reveals the binding specificity of BiP. Cell 75: 717-728.

Bonfanti R, Colombo C, Nocerino V, Massa O, Lampasona V, Iafusco D, Viscardi M, Chiumello G, Meschi F, Barbetti F. 2009. Insulin gene mutations as cause of diabetes in children negative for five type 1 diabetes autoantibodies. Diabetes Care 32: 123-125.

Braakman I, Bulleid NJ. 2011. Protein folding and modification in the mammalian endoplasmic reticulum. Annu Rev Biochem 80: 71-99.

Braakman I, Hoover-Litty H, Wagner KR, Helenius A. 1991. Folding of influenza hemagglutinin in the endoplasmic reticulum. J Cell Biol 114: 401-411.

Braakman I, Helenius J, Helenius A. 1992a. Manipulating disulfide bond formation and protein folding in the endoplasmic reticulum. EMBO J 11: 1717-1722.

Braakman I, Helenius J, Helenius A. 1992b. Role of ATP and disulphide bonds during protein folding in the endoplasmic reticulum. Nature 356: 260-262.

Brandts JF, Brennan M, Lung-Nan L. 1977. Unfolding and refolding occur much faster for a proline-free proteins than for most proline-containing proteins. Proc Natl Acad Sci 74: 4178-4181.

* Bulleid NJ. 2012. Disulfide bond formation in the mammalian endoplasmic reticulum. Cold Spring Harb Perspect Biol 4: a013219.
Caramelo JJ, Parodi AJ. 2008. Getting in and out from calnexin/calreticulin cycles. J Biol Chem 283: 10221-10225.

Caramelo JJ, Castro OA, Alonso LG, de Prat-Gay G, Parodi AJ. 2003. UDP-Glc:glycoprotein glucosyltransferase recognizes structured and solvent accessible hydrophobic patches in molten globule-like folding intermediates. Proc Natl Acad Sci 100: 86-91.

Caramelo JJ, Castro OA, de Prat-Gay G, Parodi AJ. 2004. The endoplasmic reticulum glucosyltransferase recognizes nearly native glycoprotein folding intermediates. J Biol Chem 279: 46280-46285.

Chen Y, Hu D, Yabe R, Tateno H, Qin SY, Matsumoto N, Hirabayashi J, Yamamoto K. 2011. Role of malectin in $\operatorname{Glc}(2) \operatorname{Man}(9) \operatorname{GlcNAc}(2)$-dependent quality control of a1-antitrypsin. Mol Biol Cell 22: 3559-3570.

Christianson JC, Shaler TA, Tyler RE, Kopito RR. 2008. OS-9 and GRP94 deliver mutant $\alpha 1$-antitrypsin to the Hrd1SEL1L ubiquitin ligase complex for ERAD. Nat Cell Biol 10: $272-282$.

Chung KT, Shen Y, Hendershot LM. 2002. BAP, a mammalian BiP-associated protein, is a nucleotide exchange factor that regulates the ATPase activity of BiP. J Biol Chem 277: 47557-47563.

Daniels R, Kurowski B, Johnson AE, Hebert DN. 2003. Nlinked glycans direct the cotranslational folding pathway of influenza hemagglutinin. Mol Cell 11: 79-90.

Ding B, Kull B, Liu Z, Mottagui-Tabar S, Thonberg H, Gu HF, Brookes AJ, Grundemar L, Karlsson C, Hamsten A, et al. 2005. Human neuropeptide Y signal peptide gain-of-function polymorphism is associated with increased body mass index: Possible mode of function. Regul Pept 127(1-3): 45-53.

Doms RW, Ruusala A, Machamer C, Helenius J, Helenius A, Rose JK. 1988. Differential effects of mutations in three domains on folding, quaternary structure, and intracellular transport of vesicular stomatitis virus $\mathrm{G}$ protein. $J$ Cell Biol 107: 89-99.

Duga S, Montefusco MC, Asselta R, Malcovati M, Peyvandi F, Santagostino E, Mannucci PM, Tenchini ML. 2003. Arg2074Cys missense mutation in the $\mathrm{C} 2$ domain of factor $\mathrm{V}$ causing moderately severe factor $\mathrm{V}$ deficiency: Molecular characterization by expression of the recombinant protein. Blood 101: 173-177.

Dutta R, Inouye M. 2000. GHKL, an emergent ATPase/kinase superfamily. Trends Biochem Sci 25: 24-28.

Earl PL, Moss B, Doms RW. 1991. Folding, interaction with GRP78-BiP, assembly and transport of the human immunodeficiency virus typel envelope protein. J Virol 65: 2047-2055.

Ellgaard L, Ruddock LW. 2005. The human protein disulphide isomerase family: Substrate interactions and functional properties. EMBO Rep 6: $28-32$.

Ellis RJ, Hartl FU. 1999. Principles of protein folding in the cellular environment. Curr Opin Struct Biol 9: 102-110.

Ellis RJ, Van der Vies SM. 1991. Molecular chaperones. Annu Rev Biochem 60: 321-347.

Flynn GC, Pohl J, Flocco MT, Rothman JE. 1991. Peptidebinding specificity of the molecular chaperone $\mathrm{BiP} . \mathrm{Na}$ ture 353: 726-730.

Frickel EM, Riek R, Jelesarov I, Helenius A, Wuthrich K, Ellgaard L. 2002. TROSY-NMR reveals interaction 
I. Braakman and D.N. Hebert

between ERp57 and the tip of the calreticulin P-domain. Proc Natl Acad Sci 99: 1954-1959.

Galli C, Bernasconi R, Solda T, Calanca V, Molinari M. 2011. Malectin participates in a backup glycoprotein quality control pathway in the mammalian ER. PLoS ONE 6: e16304.

Gamou S, Shimagaki M, Minoshima S, Kobayashi S, Shimizu N. 1989. Subcellular localization of the EGF receptor maturation process. Exp Cell Res 183: 197-206.

Geiger R, Gautschi M, Thor F, Hayer A, Helenius A. 2011. Folding, quality control, and secretion of pancreatic ribonuclease in live cells. J Biol Chem 286: 5813-5822.

Guerin M, Parodi AJ. 2003. The UDP-glucose:Glycoprotein glucosyltransferase is organized in at least two tightly bound domains from yeast to mammals. J Biol Chem 278: $20540-20546$.

Hainzl O, Lapina MC, Buchner J, Richter K. 2009. The charged linker region is an important regulator of Hsp90 function. J Biol Chem 284: 22559-22567.

Hammond C, Braakman I, Helenius A. 1994. Role of Nlinked oligosaccharides, glucose trimming and calnexin during glycoprotein folding in the endoplasmic reticulum. Proc Natl Acad Sci 91: 913-917.

Hanson SR, Culyba EK, Hsu TL, Wong CH, Kelly JW, Powers ET. 2009. The core trisaccharide of an $\mathrm{N}$-linked glycoprotein intrinsically accelerates folding and enhances stability. Proc Natl Acad Sci 106: 3131-3136.

Hebert DN, Foellmer B, Helenius A. 1995. Glucose trimming and reglucosylation determine glycoprotein association with calnexin in the endoplasmic reticulum. Cell 81: $425-433$.

Hebert DN, Foellmer B, Helenius A. 1996. Calnexin and calreticulin promote folding, delay oligomerization and suppress degradation of influenza hemagglutinin in microsomes. EMBO J 15: 2961-2968.

Hebert DN, Zhang JX, Chen W, Foellmer B, Helenius A. 1997. The number and location of glycans on influenza hemagglutinin determine folding and association with calnexin and calreticulin. J Cell Biol 139: 613-623.

Hebert DN, Garman SC, Molinari M. 2005. The glycan code of the endoplasmic reticulum: Asparagine-linked carbohydrates as protein maturation and quality-control tags. Trends Cell Biol 15: 364-370.

Hegde RS, Bernstein HD. 2006. The surprising complexity of signal sequences. Trends Biochem Sci 31: 563-571.

Helenius A, Aebi M. 2004. Roles of $N$-linked glycans in the endoplasmic reticulum. Annu Rev Biochem 73: 10191049.

Hendershot LM. 2004. The ER function BiP is a master regulator of ER function. Mt Sinai J Med 71: 289-297.

Hendershot L, Bole D, Köhler G, Kearney JF. 1987. Assembly and secretion of heavy chains that do not associate posttranslationally with immunoglobulin heavy chain binding protein. J Cell Biol 104: 761-767.

Hendriks G, Koudijs M, van Balkom BW, Oorschot V, Klumperman J, Deen PM, van der Sluijs P. 2004. Glycosylation is important for cell surface expression of the water channel aquaporin-2 but is not essential for tetramerization in the endoplasmic reticulum. J Biol Chem 279: $2975-2983$.
Hoelen H, Kleizen B, Schmidt A, Richardson J, Charitou P Thomas PJ, Braakman I. 2010. The primary folding defect and rescue of $\triangle F 508$ CFTR emerge during translation of the mutant domain. PLoS ONE 5: e15458.

Hogue BG, Nayak DP. 1992. Synthesis and processing of the influenza virus neuraminidase, a type II transmembrane glycoprotein. Virology 188: 510-517.

Hubbard SC, Robbins PW. 1979. Synthesis and processing of protein-linked oligosaccharides in vivo. J Biol Chem 254: $4568-4576$.

Ishiguro S, Watanabe Y, Ito N, Nonaka H, Takeda N, Sakai T, Kanaya H, Okada K. 2002. SHEPHERD is the Arabidopsis GRP94 responsible for the formation of functional CLAVATA proteins. EMBO J 21: 898-908.

Jakob RP, Schmid FX. 2009. Molecular determinants of a native-state prolyl isomerization. J Mol Biol 387: 1017 1031.

Jansen G, Maattanen P, Denisov AY, Scarffe L, Schade B, Balghi H, Dejgaard K, Chen LY, Muller WJ, Gehring K, et al. 2012. An interaction map of ER chaperones and foldases. Mol Cell Proteomics 11: 710-723.

Jansens A, van Duijn E, Braakman I. 2002. Coordinated nonvectorial folding in a newly synthesized multidomain protein. Science 298: 2401-2403.

Jitsuhara Y, Toyoda T, Itai T, Yamaguchi H. 2002. Chaperone-like functions of high-mannose type and complextype $N$-glycans and their molecular basis. J Biochem 132: 803-811.

Khanna R, Myers MP, Laine M, Papazian DM. 2001. Glycosylation increases potassium channel stability and surface expression in mammalian cells. J Biol Chem 276: 34028 34034.

Kim PS, Arvan P. 1991. Folding and assembly of newly synthesized thyroglobulin occurs in a pre-Golgi compartment. J Biol Chem 266: 12412-12418.

Klappa P, Freedman RB, Zimmerman R. 1995. Protein disulfide isomerase and a lumenal cylcophilin-type peptidyl prolyl cis-trans isomerase are in transient contact with secretory proteins during late stages of translocation. Eur J Biochem 232: 755-764.

Kleizen B, Braakman I. 2004. Protein folding and quality control in the endoplasmic reticulum. Curr Opin Cell Biol 16: 343-349.

Knappe TA, Eckert B, Schaarschmidt P, Scholz C, Schmid FX. 2007. Insertion of a chaperone domain converts FKBP12 into a powerful catalyst of protein folding. J Mol Biol 368: 1458-1468.

Kozlov G, Bastos-Aristizabal S, Maattanen P, Rosenauer A, Zheng F, Killikelly A, Trempe JF, Thomas DY, Gehring K. 2010. Structural basis of cyclophilin B binding by the calnexin/calreticulin P-domain. J Biol Chem 285: 3555135557.

Kundra R, Kornfeld S. 1999. Asparagine-linked oligosaccharides protect Lamp-1 and Lamp-2 from intracellular proteolysis. J Biol Chem 274: 31039-31046.

Labriola C, Cazzulo JJ, Parodi AJ. 1995. Retention of glucose units added by the UDP-GLC:glycoprotein glucosyltransferase delays exit of glycoproteins from the endoplasmic reticulum. J Cell Biol 130: 771-779.

Lambert G, Becker B, Schreiber R, Boucherot A, Reth M, Kunzelmann K. 2001. Control of cystic fibrosis 
transmembrane conductance regulator expression by BAP31. J Biol Chem 276: 20340-20345.

Land A, Zonneveld D, Braakman I. 2003. Folding of HIV-1 envelope glycoprotein involves extensive isomerization of disulfide bonds and conformation-dependent leader peptide cleavage. FASEB J 17: 1058-1067.

Lang K, Schmid FX, Fischer G. 1987. Catalysis of protein folding by prolyl isomerase. Nature 329: 268-270.

Lehrman MA. 2001. Oligosaccharide-based information in the endoplasmic reticulum quality control and other biological systems. J Biol Chem 276: 8623-8626.

Li Y, Bergeron JJ, Luo L, Ou WJ, Thomas DY, Kang CY. 1996. Effects of inefficient cleavage of the signal sequence of HIV-1 gp 120 on its association with calnexin, folding, and intracellular transport. Proc Natl Acad Sci 93: 96069611.

Lin Y, Lee H, Berg AH, Lisanti MP, Shapiro L, Scherer PE. 2000. The lipopolysaccharide-activated toll-like receptor (TLR)-4 induces synthesis of the closely related receptor TLR-2 in adipocytes. J Biol Chem 275: 24255-24263.

Lizak C, Fan YY, Weber TC, Aebi M. 2011. N-Linked glycosylation of antibody fragments in Escherichia coli. Bioconjug Chem 22: 488-496.

Lodish HF, Kong N. 1984. Glucose removal from N-linked oligosaccharides is required for efficient maturation of certain secretory glycoproteins from the rough endoplasmic reticulum to the Golgi complex. J Cell Biol 98: $1720-1729$.

Lodish HF, Kong N, Snider M, Strous GA.M. 1983. Hepatoma secretory proteins migrate from the endoplasmic reticulum to Golgi at characteristic rates. Nature 304: $80-83$.

Maynard JC, Pham T, Zheng T, Jockheck-Clark A, Rankin HB, Newgard CB, Spana EP, Nicchitta CV. 2010. Gp93, the Drosophila GRP94 ortholog, is required for gut epithelial homeostasis and nutrient assimilationcoupled growth control. Dev Biol 339: 295-306.

Melnick J, Dul JL, Argon Y. 1994. Sequential interaction of the chaperones BiP and GRP94 with immunoglobulin chains in the endoplasmic reticulum. Nature 370: 373375 .

Mendes F, Roxo Rosa M, Dragomir A, Farinha CM, Roomans GM, Amaral MD, Penque D. 2003. Unusually common cystic fibrosis mutation in Portugal encodes a misprocessed protein. Biochem Biophys Res Commun 311: 665-671.

Merlie JP, Lindstrom J. 1983. Assembly in vivo of mouse muscle acetylcholine receptor: Identification of an $\alpha$ subunit species that may be an assembly intermediate. Cell 34: $747-757$.

Meunier L, Usherwood Y-K, Chung KT, Hendershot LM 2002. A subset of chaperones and folding enzymes from multiprotein complexes in the endoplasmic reticulum to bind nascent proteins. Mol Biol Cell 13: 4456-4469.

Molinari M, Helenius A. 2000. Chaperone selection during glycoprotein translocation into the endoplasmic reticulum. Science 288: 331-333.

Molinari M, Galli C, Vanoni O, Arnold SM, Kaufman RJ. 2005. Persistent glycoprotein misfolding activates the glucosidase II/UGT1-driven calnexin cycle to delay ag- gregation and loss of folding competence. Mol Cell 20: 503-512.

Nicchitta CV, Murphy EC, Haynes R, Shelness GS. 1995. Stage- and ribosome-specific alterations in nascent chain-Sec61p interactions accompany translocation across the ER membrane. J Cell Biol 129: 957-970.

Nilsson I, von Heijne G. 1993. Determination of the distance between oligosaccharyltranferase active site and the endoplasmic reticulum membrane. J Biol Chem 268: 57985801.

Oliver JD, van der, Wal Fj, Bulleid NJ, High S. 1997. Interaction of the thiol-dependent reductase ERp57 with nascent glycoproteins. Science 275: 86-88.

Oliver JD, Roderick HL, Llewellyn DH, High S. 1999. ERp57 functions as a subunit of specific complexes formed with the ER lectins calreticulin and calnexin. Mol Biol Cell 10: 2573-2582.

Ostrovsky O, Ahmed NT, Argon Y. 2009. The chaperone activity of GRP94 toward insulin-like growth factor II is necessary for the stress response to serum deprivation. Mol Biol Cell 20: 1855-1864.

Otero JH, Lizak B, Hendershot LM. 2010. Life and death of a BiP substrate. Semin Cell Dev Biol 21: 472-478.

Pappenberger G, Aygun H, Engels JW, Reimer U, Fischer G, Kiefhaber T. 2001. Nonprolyl cis peptide bonds in unfolded proteins cause complex folding kinetics. Nat Struct Biol 8: 452-458.

Pearse BR, Hebert DN. 2010. Lectin chaperones help direct the maturation of glycoproteins in the endoplasmic reticulum. Biochim Biophys Acta 1803: 684-693.

Pearse BR, Gabriel L, Wang N, Hebert DN. 2008. A cellbased reglucosylation assay demonstrates the role of GT1 in the quality control of a maturing glycoprotein. $J$ Cell Biol 181: 309-320.

Pearse BR, Tamura T, Sunryd JC, Grabowski GA, Kaufman RJ, Hebert DN. 2010. The role of UDP-Glc:glycoprotein glucosyltransferase 1 in the maturation of an obligate substrate prosaposin. J Cell Biol 189: 829-841.

Pena F, Jansens A, van Zadelhoff G, Braakman I. 2010. Calcium as a crucial cofactor for low density lipoprotein receptor folding in the endoplasmic reticulum. J Biol Chem 285: 8656-8664.

Petersen TN, Brunak S, von Heijne G, Nielsen H. 2011. SignalP 4.0: Discriminating signal peptides from transmembrane regions. Nat Methods 8: 785-786.

Peterson JR, Ora A, Nguyen Van P, Helenius A. 1995. Transient, lectin-like association of calreticulin with folding intermediates of cellular and viral glycoproteins. Mol Biol Cell 6: 1173-1184.

Piersma D, Berns EM, Verhoef-Post M, Uitterlinden AG, Braakman I, Pols HA, Themmen AP. 2006. A common polymorphism renders the luteinizing hormone receptor protein more active by improving signal peptide function and predicts adverse outcome in breast cancer patients. J Clin Endocrinol Metab 91: 1470-1476.

Pollock S, Kozlov G, Pelletier MF, Trempe JF, Jansen G, Sitnikov D, Bergeron JJ, Gehring K, Ekiel I, Thomas DY. 2004. Specific interaction of ERp57 and calnexin determined by NMR spectroscopy and an ER two-hybrid system. EMBO J 23: 1020-1029. 
I. Braakman and D.N. Hebert

Popescu CI, Paduraru C, Dwek RA, Petrescu SM. 2005 Soluble tyrosinase is an endoplasmic reticulum (ER)-associated degradation substrate retained in the ER by calreticulin and BiP/GRP78 and not calnexin. J Biol Chem 280: $13833-13840$.

Popp MW, Karssemeijer RA, Ploegh HL. 2012. Chemoenzymatic site-specific labeling of influenza glycoproteins as a tool to observe virus budding in real time. PLoS Pathog 8: e1002604.

Rajagopalan S, Xu Y, Brenner MB. 1994. Retention of unassembled components of integral membrane proteins by calnexin. Science 263: 387-390.

Randow F, Seed B. 2001. Endoplasmic reticulum chaperone gp96 is required for innate immunity but not cell viability. Nat Cell Biol 3: 891-896.

Rane NS, Chakrabarti O, Feigenbaum L, Hegde RS. 2010. Signal sequence insufficiency contributes to neurodegeneration caused by transmembrane prion protein. $J$ Cell Biol 188: 515-526.

Ruiz-Canada C, Kelleher DJ, Gilmore R. 2009. Cotranslational and posttranslational $\mathrm{N}$-glycosylation of polypeptides by distinct mammalian OST isoforms. Cell 136: $272-283$.

Rutkevich LA, Cohen-Doyle MF, Brockmeier U, Williams DB. 2010. Functional relationship between protein disulfide isomerase family members during the oxidative folding of human secretory proteins. Mol Biol Cell 21: 3093-3105.

Schallus T, Jaeckh C, Feher K, Palma AS, Liu Y, Simpson JC, Mackeen M, Stier G, Gibson TJ, Feizi T, et al. 2008 Malectin: A novel carbohydrate-binding protein of the endoplasmic reticulum and a candidate player in the early steps of protein N-glycosylation. Mol Biol Cell 19: $3404-$ 3414.

Schauble N, Lang S, Jung M, Cappel S, Schorr S, Ulucan O, Linxweiler J, Dudek J, Blum R, Helms V, et al. 2012. BiPmediated closing of the Sec61 channel limits $\mathrm{Ca}^{2+}$ leakage from the ER. EMBO J 31: 3282-3296.

Schiene-Fischer C, Habazettl J, Schmid FX, Fischer G. 2002. The hsp70 chaperone DnaK is a secondary amide peptide bond cis-trans isomerase. Nat Struct Biol 9: 419-424.

Schrag JD, Bergeron JJ, Li Y, Borisova S, Hahn M, Thomas DY, Cygler M. 2001. The structure of calnexin an ER chaperone involved in quality control of protein folding. Mol Cell 8: 633-644.

Schulte TW, Akinaga S, Murakata T, Agatsuma T, Sugimoto S, Nakano H, Lee YS, Simen BB, Argon Y, Felts S, et al. 1999. Interaction of radicicol with members of the heat shock protein 90 family of molecular chaperones. Mol Endocrinol 13: 1435-1448.

Schulteis CT, John SA, Huang Y, Tang CY, Papazian DM. 1995. Conserved cysteine residues in the shaker $\mathrm{K}^{+}$channel are not linked by a disulfide bond. Biochemistry 34: 1725-1733.

Senderek J, Krieger M, Stendel C, Bergmann C, Moser M, Breitbach-Faller N, Rudnik-Schoneborn S, Blaschek A, Wolf NI, Harting I, et al. 2005. Mutations in SIL1 cause Marinesco-Sjogren syndrome, a cerebellar ataxia with cataract and myopathy. Nat Genet 37: 1312-1314.

Shaffer KL, Sharma A, Snapp EL, Hegde RS. 2005. Regulation of protein compartmentalization expands the diversity of protein function. Dev Cell 9: 545-554.
Shakin-Eshleman SH, Remaley AT, Eshleman JR, Wunner WH, Spitalnik SL. 1992. N-linked glycosylation of rabies virus glycoprotein. Individual sequons differ in their glycosylation efficiencies and influence on cell surface expression. J Biol Chem 267: 10690-10698.

Singh I, Doms RW, Wagner KR, Helenius A. 1990. Intracellular transport of soluble and membrane-bound glycoproteins: Folding, assembly and secretion of anchor-free influenza hemagglutinin. EMBO J 9: 631-639.

Skehel JJ, Stevens DJ, Daniels RS, Douglas AR, Knossow M, Wilson IA, Wiley DC. 1984. A carbohydrate side chain on hemagglutinins of Hong Kong influenza viruses inhibits recognition by a monoclonal antibody. Proc Natl Acad Sci 81: 1779-1783.

Solda T, Garbi N, Hammerling GJ, Molinari M. 2006. Consequences of ERp57 deletion on oxidative folding of obligate and facultative clients of the calnexin cycle. J Biol Chem 281: 6219-6226.

Soldano KL, Jivan A, Nicchitta CV, Gewirth DT. 2003. Structure of the N-terminal domain of GRP94. Basis for ligand specificity and regulation. J Biol Chem 278: 4833048338.

Sousa M, Parodi AJ. 1995. The molecular basis for the recognition of misfolded glycoproteins by the UDP-Glc: Glycoprotein glucosyltransferase. EMBO J 14: 41964203.

Srivastava PK. 2006. Therapeutic cancer vaccines. Curr Opin Immunol 18: 201-205.

Straub SG, Sharp GW. 2002. Glucose-stimulated signaling pathways in biphasic insulin secretion. Diabetes Metab Res Rev 18: 451-463.

Suh P, Bergmann JE, Gabel CA. 1989. Selective retention of monoglycosylated high mannose oligosaccarides by a class of mutant vesicular stomatitis virus $\mathrm{G}$ proteins. J Cell Biol 108: 811-819.

Swanton E, Bulleid NJ. 2003. Protein folding and translocation across the endoplasmic reticulum membrane. $\mathrm{Mol}$ Membr Biol 20: 99-104.

Tamura T, Cormier JH, Hebert DN. 2011. Characterization of early EDEM1 protein maturation events and their functional implications. J Biol Chem 286: 24906-24915.

Tatu U, Braakman I, Helenius A. 1993. Membrane glycoprotein folding, oligomerization and intracellular transport: Effects of dithiothreitol in living cells. EMBO J 12: 21512157.

Thor F, Gautschi M, Geiger R, Helenius A. 2009. Bulk flow revisited: Transport of a soluble protein in the secretory pathway. Traffic 10: 1819-1830.

van der Zand A, Gent J, Braakman I, Tabak HF. 2012. Biochemically distinct vesicles from the endoplasmic reticulum fuse to form peroxisomes. Cell 149: 397-409.

Van Leeuwen JEM, Kearse KP. 1997. Reglucosylation of Nlinked glycans is critical for calnexin assembly with $\mathrm{T}$ cell receptor (TCR) $\alpha$ proteins but not TCR $\beta$ proteins. J Biol Chem 272: 4179-4186.

Vassilakos A, Cohen-Doyle MF, Peterson PA, Jackson MR, Williams DB. 1996. The molecular chaperone calnexin facilitates folding and assembly of class I histocompatibility molecules. EMBO J 15: 1495-1506.

Visintin A, Mazzoni A, Spitzer JA, Segal DM. 2001. Secreted MD-2 is a large polymeric protein that efficiently confers 
lipopolysaccharide sensitivity to Toll-like receptor 4. Proc Natl Acad Sci 98: 12156-12161.

Vogen S, Gidalevitz T, Biswas C, Simen BB, Stein E, Gulmen F, Argon Y. 2002. Radicicol-sensitive peptide binding to the N-terminal portion of GRP94. J Biol Chem 277: 40742-40750.

Wada I, Kai M, Imai S, Sakane F, Kanoh H. 1997. Promotion of transferrin folding by cyclic interactions with calnexin and calreticulin. EMBO J 16: 5420-5432.

Wallis AK, Freedman RB. 2011. Assisting oxidative protein folding: How do protein disulphide-isomerases couple conformational and chemical processes in protein folding? Top Curr Chem doi: 10.1007/128_2011_171.

Wanderling S, Simen BB, Ostrovsky O, Ahmed NT, Vogen SM, Gidalevitz T, Argon Y. 2007. GRP94 is essential for mesoderm induction and muscle development because it regulates insulin-like growth factor secretion. Mol Biol Cell 18: 3764-3775.

Wang N, Daniels R, Hebert DN. 2005. The cotranslational maturation of the type I membrane glycoprotein tyrosinase: The heat shock protein 70 system hands off to the lectin-based chaperone system. Mol Biol Cell 16: 37403752.

Wang N, Glidden EJ, Murphy SR, Pearse BR, Hebert DN 2008. The cotranslational maturation program for the type II membrane glycoprotein influenza neuraminidase. J Biol Chem 283: 33826-33837.
Wearsch PA, Voglino L, Nicchitta CV. 1998. Structural transitions accompanying the activation of peptide binding to the endoplasmic reticulum Hsp90 chaperone GRP94. Biochemistry 37: 5709-5719.

Yamada S, Ono T, Mizuno A, Nemoto TK. 2003. A hydrophobic segment within the C-terminal domain is essential for both client-binding and dimer formation of the HSP90-family molecular chaperone. Eur J Biochem 270: 146-154.

Zapun A, Darby NJ, Tessier DC, Michalak M, Bergeron JJ, Thomas DY. 1998. Enhanced catalysis of ribonuclease B folding by the interaction of calnexin or calreticulin with ERp57. J Biol Chem 273: 6009-6012.

Zhang H, Peters KW, Sun F, Marino CR, Lang J, Burgoyne RD, Frizzell RA. 2002. Cysteine string protein interacts with and modulates the maturation of the cystic fibrosis transmembrane conductance regulator. J Biol Chem 277: 28948-28958.

Zhao L, Longo-Guess C, Harris BS, Lee JW, Ackerman SL. 2005. Protein accumulation and neurodegeneration in the woozy mutant mouse is caused by disruption of SIL1, a cochaperone of BiP. Nat Genet 37: 974-979.

Zielinska DF, Gnad F, Wisniewski JR, Mann M. 2010. Precision mapping of an in vivo $\mathrm{N}$-glycoproteome reveals rigid topological and sequence constraints. Cell 141: 897-907. 


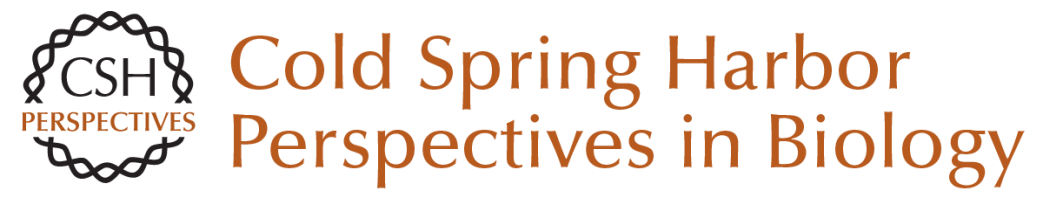

\section{Protein Folding in the Endoplasmic Reticulum}

Ineke Braakman and Daniel N. Hebert

Cold Spring Harb Perspect Biol 2013; doi: 10.1101/cshperspect.a013201

Subject Collection The Endoplasmic Reticulum

Sorting and Export of Proteins at the Endoplasmic Reticulum

Ishier Raote, Sonashree Saxena and Vivek Malhotra

Endoplasmic Reticulum Membrane Contact Sites, Lipid Transport, and Neurodegeneration Andrés Guillén-Samander and Pietro De Camilli

AMPylation and Endoplasmic Reticulum Protein Folding Homeostasis

Luke A. Perera and David Ron

The Endoplasmic Reticulum and the Fidelity of Nascent Protein Localization

Michael J. McKenna and Sichen Shao

Endoplasmic Reticulum Architecture and Inter-Organelle Communication in Metabolic Health and Disease

Ana Paula Arruda and Günes Parlakgül

Regulation and Functions of the ER-Associated

Nrf1 Transcription Factor

Gary Ruvkun and Nicolas Lehrbach

Mechanism of Protein Translocation by the Sec61

Translocon Complex

Samuel Itskanov and Eunyong Park

Evolutionary Aspects of the Unfolded Protein

Response

Kazutoshi Mori
Glycerolipid Synthesis and Lipid Droplet

Formation in the Endoplasmic Reticulum

Robert V. Farese, Jr. and Tobias C. Walther

The Biogenesis of Multipass Membrane Proteins Luka Smalinskaite and Ramanujan S. Hegde

A TAle of Two Pathways: Tail-Anchored Protein Insertion at the Endoplasmic Reticulum Alina Guna, Masami Hazu, Giovani Pinton Tomaleri, et al.

Cholesterol Transport to the Endoplasmic

Reticulum John P. Kennelly and Peter Tontonoz

The Role of the Rhomboid Superfamily in ER

Protein Quality Control: From Mechanisms and

Functions to Diseases

Satarupa Bhaduri, Nicola A. Scott and Sonya E. Neal

ER-Phagy: Quality and Quantity Control of the

Endoplasmic Reticulum by Autophagy Haruka Chino and Noboru Mizushima

Structure and Function of the Nuclear Pore Complex

Stefan Petrovic, George W. Mobbs, Christopher J. Bley, et al.

Post-Translational Regulation of HMG CoA

Reductase

Youngah Jo and Russell A. DeBose-Boyd

For additional articles in this collection, see http://cshperspectives.cshlp.org/cgi/collection/

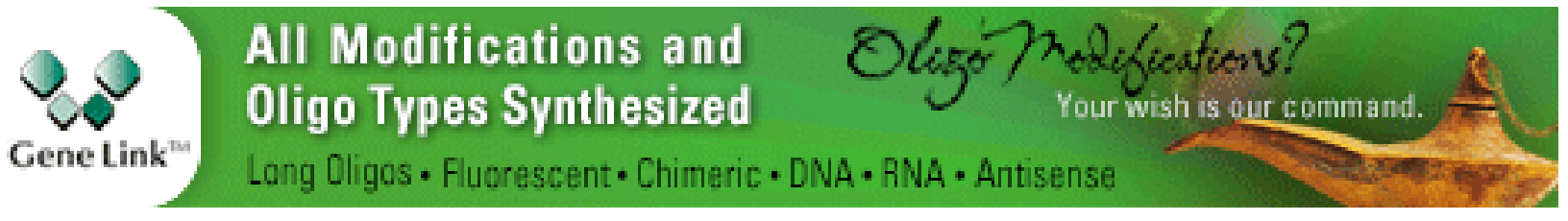


For additional articles in this collection, see http://cshperspectives.cshlp.org/cgi/collection/

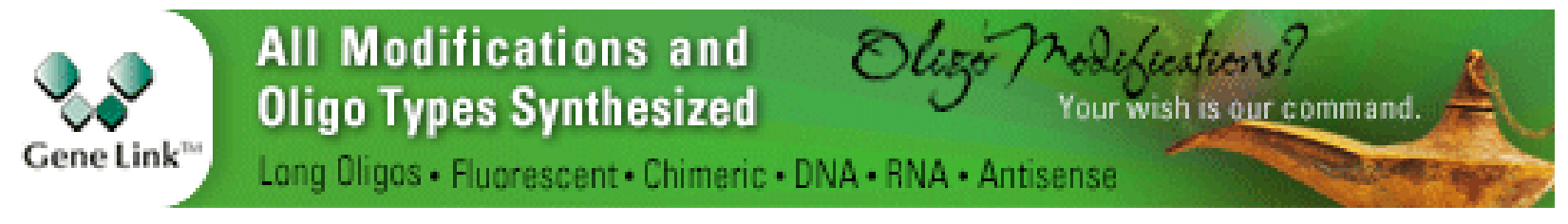

Copyright @ 2013 Cold Spring Harbor Laboratory Press; all rights reserved 